\title{
Resources to achieve esthetics in anterior teeth
}

\author{
Recursos para se obter estética em áreas anteriores
}

Luciana Elisabeth de Mattias SOUZA ${ }^{1}$

Ivete Aparecida de Mattias SARTORI'

Vitor CORÓ ${ }^{2}$

Halina Massignan BEREJUK' ${ }^{1}$

Sérgio Rocha BERNARDES ${ }^{1}$

\begin{abstract}
As dentistry has evolved, the search for good esthetics has become increasingly frequent. Professionals must be constantly up-to-date regarding the latest advances. When a tooth is lost, there are several possible rehabilitation techniques. Adequate contour of the bone and gingiva is an essential factor if good esthetic results are to be achieved. In order to maintain the contour, techniques for immediate placement of implants, bone and gum grafting techniques and care in the correct establishment of the ideal position of the implant have been advocated. Sometimes dentists have to treat a patient whose implants have already been installed and are osseointegrated. This report was carried out in order to highlight the importance of understanding the information that is available to obtain appropriate gingival contours in such clinical conditions. A review of the literature was carried out on methods for obtaining gingival papilla and esthetics in the anterior maxilla, and on methods to construct a prosthesis for the clinical case described. The analysis of the outcome and of the degree of patient satisfaction suggests that the resources described can be successfully applied.
\end{abstract}

Indexing terms: Dental esthetics. Dental implants. Gingiva. Prostheses and implants.

\section{RESUMO}

Devido às mudanças ocorridas pela evolução da Odontologia, a busca pela estética tem se tornado cada vez mais frequente. A constante atualização dos profissionais é uma necessidade. Quando ocorre a perda de um elemento dental, várias técnicas têm sido sugeridas para a correta reabilitação do mesmo. Manutenção do contorno ósseo e gengival já é um fator entendido como imprescindível para que a mesma possa ser alcançada. Em busca dessa manutenção de contorno, técnicas de posicionamentos imediatos de implantes, técnicas de enxertia óssea e/ou gengival e cuidados no correto estabelecimento da posição ideal do implante tem sido descritos. No entanto, alguns casos chegam para reabilitação com implantes já instalados e osseointegrados. Entendendo a importância de se conhecer os recursos descritos para obtenção de contornos gengivais adequados frente a essa condição clínica esse estudo foi idealizado. Foi realizada uma revisão de literatura e alguns dos métodos descritos para obtenção de papilas gengivais e estéticas em maxila anterior, assim como para confecção da prótese foram utilizados para resolução de um caso clínico que é apresentado. A análise do caso finalizado e a observação do grau de satisfação da paciente com o resultado alcançado permitem concluir que os recursos descritos são aplicáveis e permitem a otimização dos resultados.

Termos de indexação: Estética dentária. Implantes dentários. Gengiva. Próteses e implantes.

\section{INTRODUCTION}

In the $20^{\text {th }}$ century, the introduction of the concept of osseointegration introduced the possibility of the rehabilitation of completely edentulous patients using implants ${ }^{1-2}$. After various studies and research, cases of partial edentulism also started to be treated using this technique ${ }^{3}$, though it was always required to wait 6 months for healing before being able to fit the prosthetic rehabilitation. The installation of implants immediately following tooth extraction has been described ${ }^{4}$, which evolved later on into the immediate installation of the prosthetic part 5 .

Irrespective of the technique adopted for the installation of implants, the replacement of lost dental elements requires the gingival margin to be maintained at the correct height and thickness, it being of the utmost importance for the esthetic end result ${ }^{6-7}$. To this end, it has become necessary to install implants observing the following criteria: greater apical positioning in a vertical direction ${ }^{8}$; installation at a distance greater than or equal to $3 \mathrm{~mm}$ between implants or between the natural teeth

\footnotetext{
1 Instituto Latino Americano de Pesquisa e Ensino Odontológico. Rua Jacarezinho, 656, Mercês, 80710-150, Curitiba, PR, Brasil. Correspondência para/ Correspondence to: LEM SOUZA.E-mail:<luciana@oralimplant.com.br>.

2 Universidade São Paulo, Faculdade de Odontologia. São Paulo, SP, Brasil.
} 
and the implants; fitting at a distance of $2 \mathrm{~mm}$ from the cement-enamel junction of the adjacent tooth ${ }^{9}$; and fixation in sufficient bone dimension to guarantee the primary stability of the implant. By observing these implant installation procedures, with understanding, discernment and skill, excellence can be achieved in the area of osseointegrated implants, guaranteeing healthiness and esthetics for the peri-implant tissue, with the formation of papillae and the longevity of the restoration treatment ${ }^{10}$.

There are various techniques which have been described to improve esthetics in respect of implant treatment, including the increase of bone tissue and/or conjunctive tissue, guided bone regeneration, orthodontic extrusion, extraction and immediate fitting of implants, modification of surgical procedures: suture and incision techniques ${ }^{11}$. However all of these must be applied before the installation of the implants and a good number of these options are associated with high costs and lengthy treatment time. When the implants are already installed, there are very few resources described for optimizing the esthetic outcome.

One of the recommended resources is gum conditioning. This has been shown to be one of the most satisfactory and easy-to-perform clinical procedures for optimizing esthetics with prosthetic devices. It is based on the concept that the gingival tissue should form part of the prosthetic planning in order to achieve success in the esthetic, functional and biological rehabilitation ${ }^{12}$. It is also necessary, however, to understand if related techniques exist to carry out the prosthetic work after obtaining the desired soft tissue design. Thus, given the need to rehabilitate a clinical case with the absence of upper incisors and with two osseointegrated implants already installed and with problems with the design of the regular concave arc, this study was conceived with the aim of investigating the techniques reported in the literature.

\section{CASE REPORT}

Patient T.M.P., a 32 year-old female, approached the clinic run by the Latin American Institute for Dental Research and Education (ILAPEO) in Curitiba for the rehabilitation of her maxillary anterior area. The patient presented with missing elements 12, 11, 21, 22 (Figure $1 \mathrm{~A})$ and received 2 Morse Cone type implants (Neodent, Curitiba, Brazil), at positions 11 and 21 (Figure 1B).
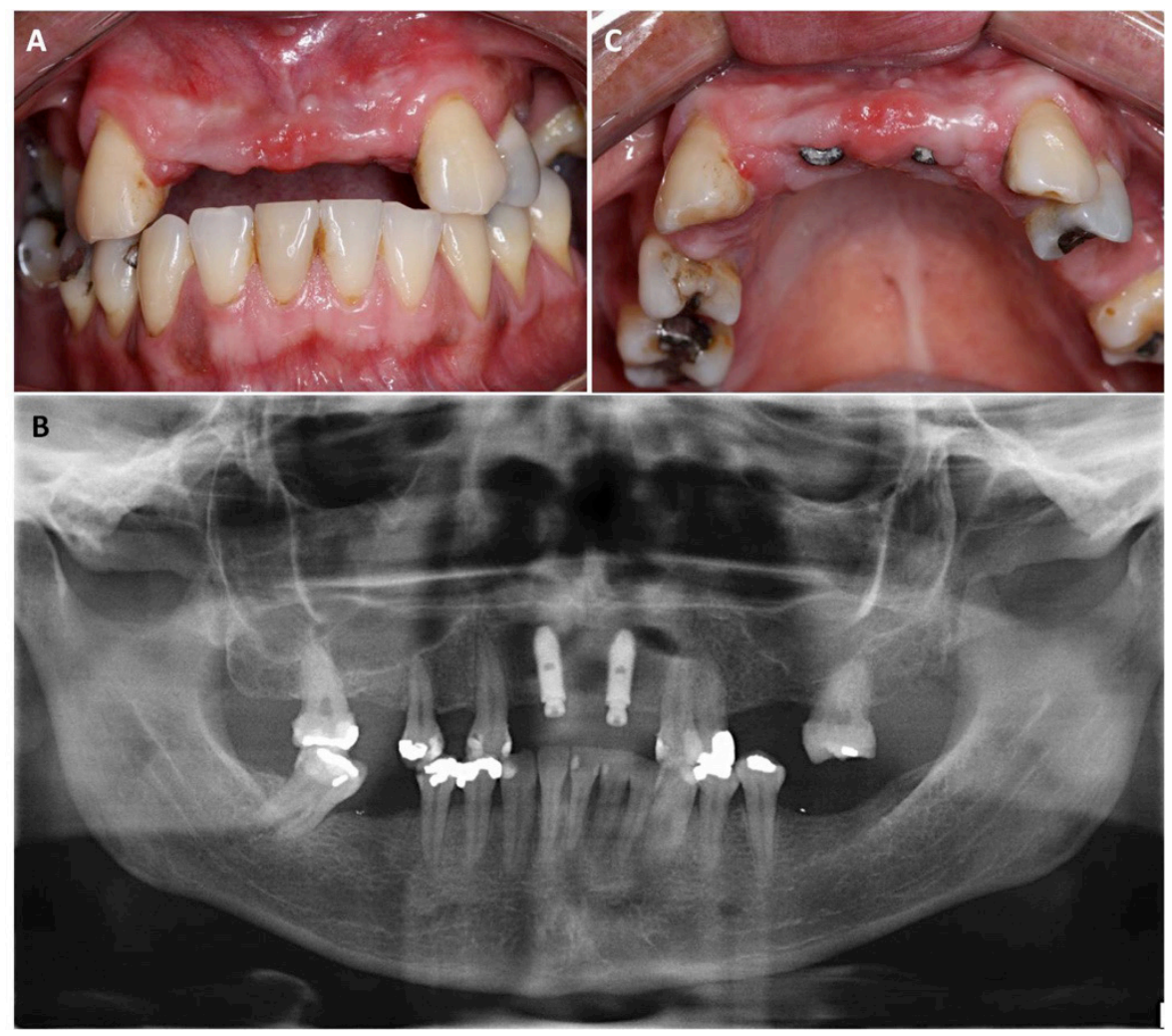

Figure 1. A) Initial photograph of the case; B) Panoramic view with implants already installed; C) Irregularity of the concave arc. 
After the period of osseointegration, with the reopening surgery having been performed and with the cicatrizants already in place, it was noted that the height of the gingival tissue was not beneficial to the correct emergence profile of the crowns and that, if no maneuver were to be engaged, the crowns on the implants would not have a regular concave arc format compatible with the existing canines (Figure $1 \mathrm{C}$ ). So the choice of the abutment height was made based on the height of the necks of the incisors which it was intended to make and not on the quantity of gingival tissue available (Figure 2A). The abutments were installed (conical mini pillar - Neodent, Curitiba, Brazil), with a torque of $32 \mathrm{Ncm}$. The molding components were installed, bonded with Pattern resin (GC America Inc., Alsip, IL, USA) and the molding was performed using condensation silicone (Speedex - Coltène, Altstätten,
SG, Switzerland). The interocclusal recording was performed using brass cylinders that were bonded using the same resin and the recorded occlusal contact (Figure 2B).

The prosthetist was instructed to create the temporary crowns with a neck height compatible with the canine neck height. As there was a lot of gingival tissue and the implants were located in a palatine position (position for a screwed prosthesis), it was deemed there was a need for conditioning so that the contour of the necks of the teeth could have a natural emergence profile. It was also deemed appropriate for the conditioning to be carried out in stages, as it would not be possible to obtain the desired format without harming tissue health. Accordingly, a neck format at the ideal height and an initial concave bridge format were requested to protect the tissue from excess pressure (Figure 2C).
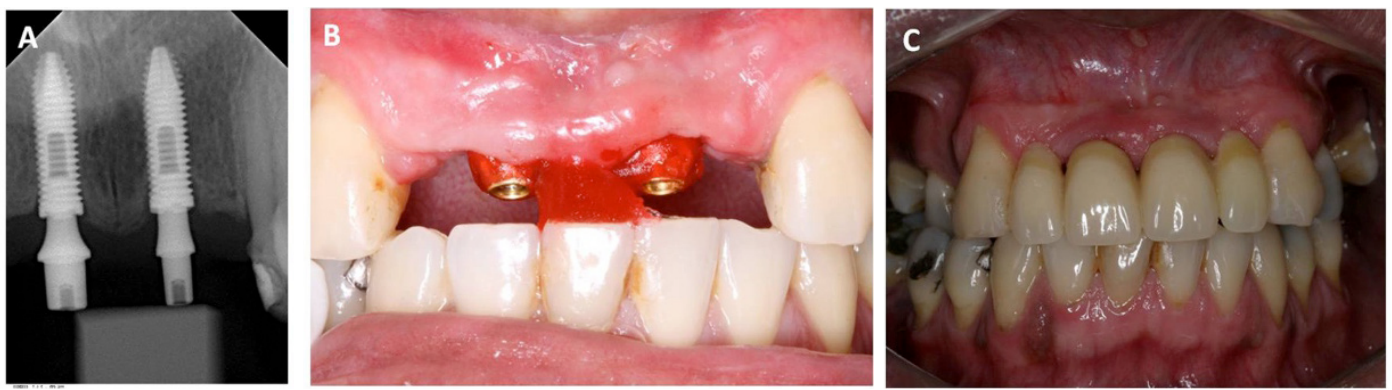

Figure 2. A) Choice of components; B) Interocclusal recording; C) Installation of the temporary crowns.

The crowns were fitted during the installation session. Ischemia occurred but it was momentary. The crowns were adjusted and an appointment was made for the patient for the following day. At the return visit, the prosthesis was removed and its format could already be seen in the gingival tissue, which was seen to be healthy (Figure 3A).

The gum conditioning then began, performed through a gradual increase in acrylic resin (Duralay, Reliance, Dental Mfg. Co., Worth, IL, USA) in the concave part of the teeth and dummy teeth (Figure 3B). Upon the patient's next visit, 48 hours later, papillae could already be seen to have formed with a satisfactory emergence profile. Further conditioning was performed over 3 or 4 more sessions in order to obtain contours in the area of the dummy teeth. A quantity of $1 \mathrm{~mm}$ of the same acrylic resin was added to the cervical region of elements $12 / 11 / 21 / 22$, there was a wait while it set and then the temporary crown was moved into position, causing a compression of the area so that it would provoke a slight gingival ischemia. The temporary crown was held in position until the ischemia disappeared, approximately 2 minutes later (Figure 3C).
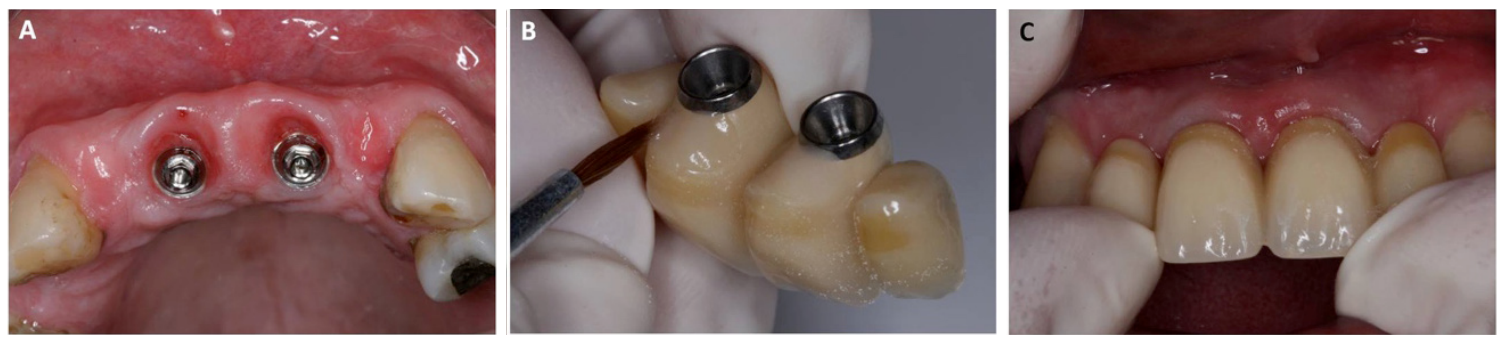

Figure 3. A) Beginning of the emergence profile; B) Addition of self-polymerizing resin; C) Tissue ischemia. 
This routine was repeated once a month until the gum was in the desired location and papilla formation was complete, in total approximately five months (Figures 4A and $4 \mathrm{~B})$.
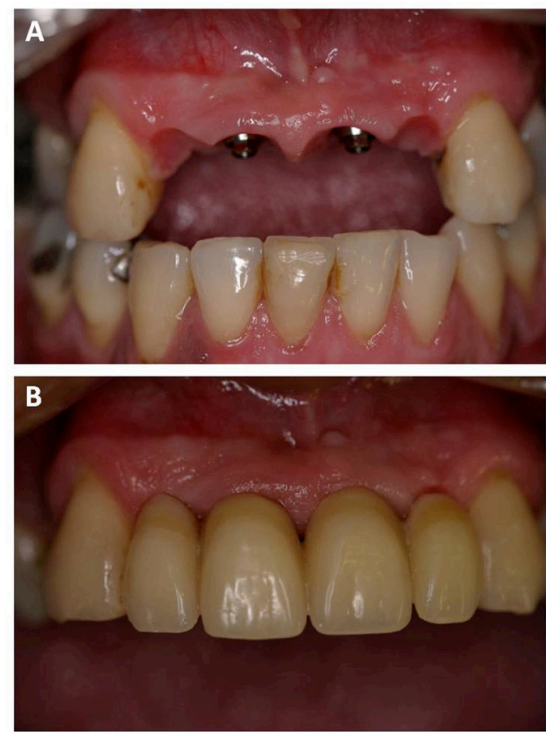

Figure 4. A) Papilla formation; B) Conclusion of conditioning.

After conditioning, as the gingival framework exhibited favorable emergence characteristics, it was deemed necessary to obtain a model that would provide its image on the laboratory bench so that the final prosthetic device could be obtained with the same favorable contours as the gingival tissue established in the temporary prosthesis. In order to obtain these models, the temporary prosthesis was removed and analogs were screwed on to it. Using heavy silicone (Speedex, Coltène, Altstätten, SG, Switzerland) the cervical portion of the temporary prosthesis was molded (Figure 5A). The temporary prostheses were removed keeping the analogs in place, thereby obtaining a mold of the cervical area of the temporary devices. The transfer dies were then screwed on to the analogs and red, inlay pattern resin (Duralay, Reliance Dental Mfg. Co., Worth, IL, USA) was poured on to this wall. In this way, a faithful copy of the position of the soft tissue was obtained after conditioning. These customized transfer dies were adapted to the mouth, bonded and then with short screws the interocclusal recording was performed. The screws were then once again replaced with long screws and the molding was performed with silicone (Speedex, Coltène, Altstätten, SG, Switzerland) (Figure 5B).
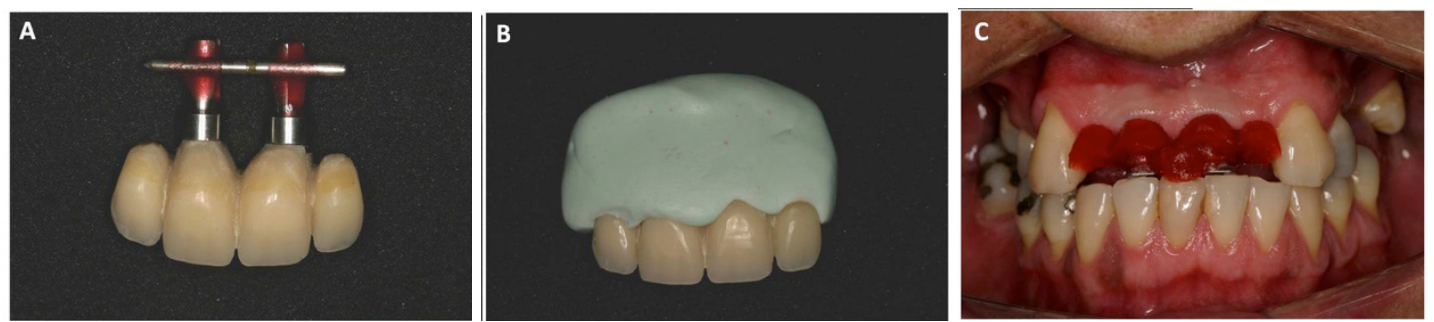

Figure 5. A and B) Copy of the emergence profile of the temporary crowns; C) Customized transfer components in place for the molding with interocclusal recording

The mold was then sent for emptying in the laboratory using special plaster of Paris. The technique chosen to prepare the prosthesis was the Neoshape CAD/ CAM system (Curitiba, Brazil) using zirconia (YZP), with the aim of obtaining esthetic results, good strength and adaptation.

The infrastructure test was carried out and excellent stability and adaptation were confirmed (Figure 6 A).

The device was then sent for the application of the porcelain. The choice of color was made in an area with natural light with the assistance of the laboratory technician, using the Vita Magnum scale. After application, the functional test was performed, esthetic and functional adjustments were established and optimal adaptation on the conditioned soft tissue was observed (Figure 6B).

The prosthesis was then finalized. It is important to stress that, during the whole period of treatment, various hygiene instruction sessions were carried out as well as supragingival and subgingival scaling. This procedure was fundamental for the clinical case to be successfully completed, in terms of periodontal health.

The patient was satisfied with the final outcome and the tissue possesses healthy characteristics (Figure 6C). The efforts of all the professionals involved was also supremely important in obtaining the end result (Figure 6D). The patient signed a consent form authorizing the publication of her clinical case. 

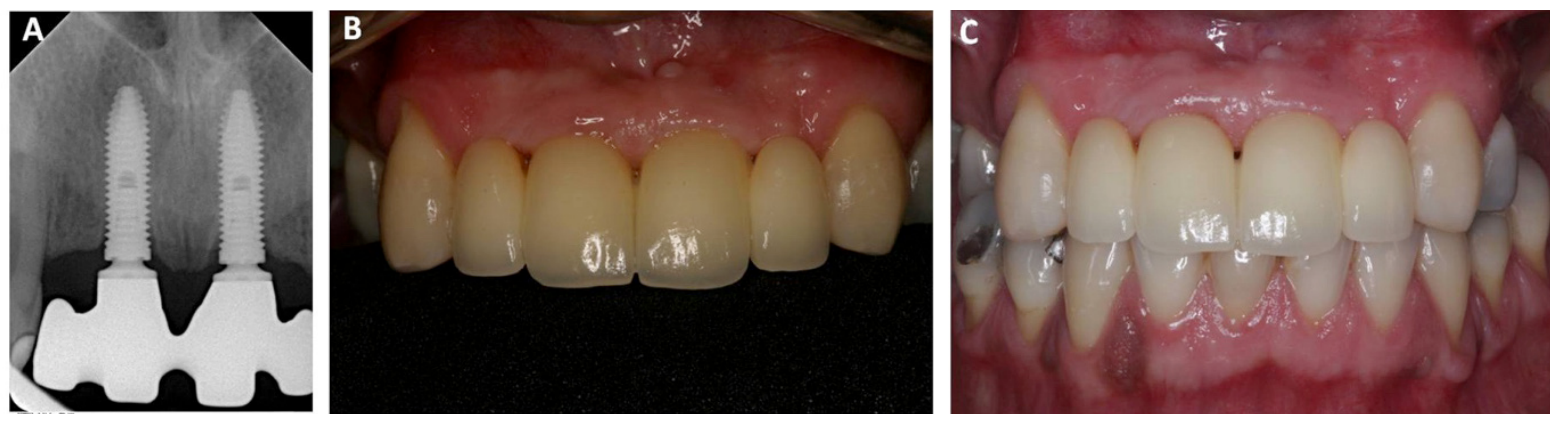

Figure 6. A) Radiograph of the structure test in zirconia; B) Installed prosthesis; C) Follow-up at 4 months.

\section{DISCUSSION}

With regard to esthetics, mainly in the maxillary anterior region, much has been discussed in the quest for improvements to finalize the prosthesis as naturally as possible and to the complete satisfaction of the patient. To this end, many techniques have been described, both in terms of the adaptation of the tissue before installation of the implants and also during the reopening and even subsequent to installation. Rosa ${ }^{8}$, in his 1993 study, described the preparation of the receiving area, after extraction, by means of an increase in conjunctive tissue and gradual pressure with the pontic itself, in order to guide the healing of the soft tissues and to obtain the desired contour. Similarly, Spear et al. ${ }^{13}$, in 2008, cited the 4 possible situations to be found prior to the fitting of the implants, defining criteria that could assist in obtaining the esthetic success of the treatment.

Nowadays esthetics are known to be an important element for the majority of patients, and therefore they must also represent an important element for the surgeons, as Meijer et al. ${ }^{14}$ in 2005 reported that esthetics are not the same for everyone, that differences even exist between surgeons and patients, each person having his/her own criteria and parameters; there are no hard and fast rules.

Good initial planning is considered to be the basis for everything and with this the end result is predictable and reliable ${ }^{15}$. Correct planning would avoid critical decision situations, even with the burying of an implant to correct defects in the supporting tissue, which could interfere with the formation of the gingival papillae ${ }^{16}$.

Techniques which seek to preserve the support structures prior to the installation of the implants are described and advocated as maintainers of esthetics and tissue quality. Of these techniques, the fitting of implants immediately after extraction is mooted in some studies ${ }^{17}$ as being favorable, while others consider that, despite the good results achieved with its use, caution is required when recommending it, especially in esthetic regions ${ }^{18}$. Buser et al. debate the need to observe a number of criteria before the technique can be recommended. These criteria are as follows: a good level of gingival margin, good bone thickness and the presence of the vestibular bone plate ${ }^{9}$. The definitive prosthesis must have an adequate shape which complements the surrounding tissue, facilitating control over plaque and occlusion, producing an agreeable appearance in conjunction with the remaining teeth. The importance of technical dominion is also referred to in a number of studies. Defects in the installation of implants with regard to trauma, bone quality and quantity and overheating are some of the factors reported in failed procedures $^{19}$.

In cases where implants are already installed, it would be of no help to know the techniques recommended for use prior to the implant installation procedure. Even having availed themselves of all the recommended criteria and care, at the moment of producing the prostheses, if the soft and hard tissue structures are not consistent with the desired esthetic, skillful maneuvering will be required in order to achieve the correct contours. As far as the resolution of the case in question is concerned, the maneuvers recommended by Jaques et al. ${ }^{20}$ were employed, consisting of the conditioning of the gingival tissue via the application of predetermined pressure in order to direct and mold the shape of the emergence profile through gradual increments of resin in the cervical region of the temporary crowns. This technique is described in and is consistent with other studies ${ }^{21,22}$ such as those of Oliveira et al. ${ }^{12}$, who identify the conditioning technique of gradual pressure to be the most beneficial. The end result was fast, efficient and low-cost, not imposing on the patient any discomfort or trauma, reaffirming the benefits that these authors report in respect of this technique. If this had not been established, the contour of the prosthesis would have to be established superimposed on the ridge, defining an 
overlapping format that would lead to the disadvantage of discomfort when performing hygiene activities and also a difficulty in obtaining esthetics, as the amount of porcelain on the ridge would not give the appearance of a pontic emerging from the gingival tissue, a factor which has been described with regard to conventional prostheses for many years ${ }^{21-22}$. With this technique, the pontic's oval format is used to determine the gradual pressure in the same way as recommended for the conventional fixed prosthesis ${ }^{12}$. This technique has limitations if the patient does not have a good quantity of keratinized mucosa, in which case periodontal surgical procedures should be recommended in order to achieve this type of tissue ${ }^{12}$.

After the correct manipulation of the soft tissue, in order to obtain a faithful copy of this area in the model, so that the laboratory can make up the final prosthesis in the same format, the technique of customizing the molding components was used ${ }^{23}$. This technique is an adaptation of techniques described for single implants ${ }^{23}$ there being authors that use the temporary prosthesis as a molding component ${ }^{24}$ and others that apply self-polymerizing resin directly to the mouth ${ }^{25}$ or photopolymerizing resin ${ }^{26}$ or an adaptation of the temporary prosthesis itself in special model ${ }^{27}$. The technique used had the advantage of taking place directly in the clinic, not having the patient wait during the emptying in order to have the prosthesis repositioned. When compared to the technique described by Bastos ${ }^{26}$, who uses photopolymerizing resin to copy the conditioned tissue in cases of single implants, it has the advantage of allowing the simultaneous copying of the entire contour of the four elements. The use of techniques that place the

\section{REFERENCES}

1. Branemårk PI, Adell R, Breine U, Hansson BO, Lindström J, Ohlsson A. Intra-osseous anchorage of dental prostheses. I. Experimental studies. Scand J Plast Reconstr Surg. 1969;3(2):81100.

2. Branemårk PI, Hansson BO, Adell R, Breine $U$, Lindström J, Hallén $\mathrm{O}$, et al. Osseointegrated Implants in the treatment of the edentulous jaw. Experience from a 10-year period. Scand J Plast Reconstr Surg. 1977;(11)suppl.16:1-132.

3. Henry PJ, Rosemberg I. Single-stage surgery for rehabilitation of the edentulous mandible. Preliminary results. Pract Periodont Aesthetic Dent. 1994;6(9):15-22.

4. Hall JA, Payne AG, Purton DG, Torr B, Duncan WJ, De Silva RK Immediately restored, single-tapered implants in the anterior maxilla: prosthodontic and aesthetic outcomes after 1 year. Clin Implant Dent Relat Res. 2007;9(1):34-45. doi: 10.1111/j.17088208.2007.00029.x transfer die and fill the space with materials directly into the mouth, could present a risk of tissue contour modification before they can be copied. Another advantage would be patient comfort in that the patient may make a return visit before the tissue suffers a modification in format and present with subsequent pain on refitting.

The fact that zirconia was chosen as the infrastructure material enabled a satisfactory color to be obtained without shadows, with good translucence and opalescence.

The patient declared herself to be satisfied and we solved her principal complaint which was the pursuit of masticatory function and esthetic benefits.

\section{CONCLUSION}

The understanding of the conditioning techniques described as well as the prosthetic molding and fabrication techniques, was important for the resolution of the case. They permitted an esthetic rehabilitation to be obtained with good conditions for ongoing comfort and hygiene.

\section{Contributors}

LEM SOUZA was responsible for planning, patient treatment and monitoring of the clinical case during the clinic sessions of the Specialization Course in Prosthodontics and participated in the composition of the article. IAM SARTORI, V CORÓ, HM BEREJUK and SR BERNARDES provided guidance on the planning, patient treatment and monitoring of the clinical case presented and participated in the composition of the article.

5. Sonick M, Hwang D. Immediate implantation. Contemp Esthet. 2007:30-5.

6. An KY, Lee JY, Kim SJ, Choi J. Perception of maxillary anterior esthetics by dental professionals and laypeople and survey of gingival topography in healthy young subjects. Int J Periodontics Restorative Dent. 2009;29(5):535-41.

7. Peñarrocha M, Lamas J, Peñarrocha M, Garcia B. Immediate maxillary lateral incisor implants with nonocclusal loading provisional crowns. J Prosthodont. 2008;17(1):55-9. doi: 10.1111/j.1532-849X.2007.00242.x

8. Rosa JCM. Manutenção da altura da margem gengival e das papilas interdentais para a implantodontia. Rev Catarin Implant.1993;2(2):2-5.

9. Buser D, Martin W, Belser UC. Optimizing esthetics for implant restorations in the anterior maxilla: anatomic and surgical considerations. Int J Oral Maxillofac Implants. 2004;19(Suppl):43-61. 
10. Mendes MTM, Ottoni J. Parâmetros previsíveis para a formação de papila periimplantar. ImplantNews. 2005;2(3):237-42.

11. Schropp L, Isidor F, Kostopoulos L, Wenzel A. Interproximal papilla levels following early versus delayed placement of singletooth implants: a controlled clinical trial. Int J Oral Maxillofac Implants. 2005;20(5):753-61.

12. Oliveira JA, Ribeiro EDP, Conti PCR, Lins A, Pegoraro LF. Condicionamento gengival: estética em tecidos moles. Rev Fac Odontol Bauru. 2002;10(2):99-104.

13. Spear FM. The use of implants and ovate pontics in the esthetic zone. Compend Contin Educ Dent. 2008;29(2):72-80.

14. Meijer HJ, Stellingsma K, Meijndert L, Raghoebar GM. A new index for rating aesthetics of implant-supported single crowns and adjacent soft tissues-the implant crown aesthetic index. Clin Oral Implants Res. 2005;16(6):645-9. doi: 10.1111/j.16000501.2005.01128.x

15. Sartori IAM. Tratamento interdisciplinar em reabilitação protética sobreimplantes. ImplantNews. 2007;4(1):10-22.

16. Al-Harbi SA. Nonsurgical management of interdental papilla associated with multiple maxillary anterior implants: a clinical report. J Prosthet Dent. 2005;93(3):212-6. doi:10.1016/j. prosdent.2004.12.015

17. Juodzbalys G, Wang HL. Soft and hard tissue assessment of immediate implant placement: a case series. Clin Oral Implants Res. 2007;18(2):237-43. doi: 10.1111/j.16000501.2006.01312.x

18. Mankoo T. Single-tooth implant restorations in the esthetic zone-contemporary concepts for optimization and maintenance of soft tissue esthetics in the replacement of failing teeth in compromised sites. Eur J Esthet Dent. 2007;2(3):274-95.

19. Levin L. Dealing with dental implant failures. J Appl Oral Sci. 2008;16(3):171-5. doi: 10.1590/\$1678-77572008000300002
20. Jacques LB, Coelho AB, Hollweg H, Conti PC. Tissue sculpturing: an alternative method for improving esthetics of anterior fixed prosthodontics. J Prosthet Dent. 1999;81(5):630-3.

21. Zavanelli AC, Dekon SFC, Zavanelli RA, Mazarro JVQ, Nepomuceno VC, Fernandes AUR. Condicionamento gengival. PCL. 2004;6(32):357-63.

22. Miraglia SS, Nogueira RP, Batista JG. Condicionamento gengival, estética periodontal e fonética. PCL. 2000;2(10):44-8.

23. Coelho AB, Miranda JES, Pegoraro LF. Single-tooth implants: a procedure to make a precise, flexible gingival contour on the master cast. J Prosthet Dent. 1997;78(1):109-10. doi:10.1016/ S0022-3913(97)70093-3

24. Attard N, Barzilay I. A modified impression technique for accurate registration of peri-implant soft tissues. J Can Dent Assoc. 2003;69(2):80-3.

25. Spyropoulou PE, Razzoog M, Sierraalta M. Restoring implants in the esthetic zone after sculpting and capturing the periimplant tissues in rest position: a clinical report. J Prosthet Dent. 2009;102(6):345-7. doi: 10.1016/S0022-3913(09)60189-X

26. Bastos PL, Nobilo MAA, Henriques GEP, Mesquita MF, Ottoboni GS, Negreiros WA. Técnica simplificada de moldagens de implantes e tecidos peri-implantares simultaneamente. Odontol Clin Cientif. 2008;7(2):165-9.

27. Elian N, Tabourian G, Jalbout ZN, Classi A, Cho SC, Froum S, et al. Accurate transfer of peri-implant soft tissue emergence profile from the provisional crown to the final prosthesis using an emergence profile cast. J Esthet Restor Dent. 2007;19(6):30614. doi: 10.1111/j.1708-8240.2007.00128.x

Received on: 2/12/2010 Final version resubmitted on: 25/6/2011 Approved on: 25/7/2011 
